\title{
PENGARUH PENGALAMAN PELANGGAN (CUSTOMER EXPERIENCE) TERHADAP KEPUASAN PELANGGAN PADA RUMAH MAKAN KULINER JAWA RANTAUPRAPAT
}

\author{
Ira Triyana Dewi ${ }^{1}$, Muhammad Irwansyah Hasibuan ${ }^{2}$ \\ ${ }^{1}$ Alumni Sarjana Ekonomi STIE Labuhanbatu \\ ${ }^{2}$ Dosen STIE Labuhanbatu
}

\begin{abstract}
ABSTRAK
Penelitian ini bertujuan untuk untuk mengetahui dan menganalisis pengaruh pengalaman pelanggan (customer experience) terhadap kepuasan pelanggan pada Rumah Makan Kuliner Jawa. Populasi dalam penelitian ini adalah para pelanggan Rumah Makan Kuliner Jawa selama waktu penelitian. Teknik pengambilan sampel menggunakan metode accidental sampling. Peneliti mengambil 96 orang pelanggan sebagai sampel. Metode analisis yang dipergunakan adalah metode analisis deskriptif, metode analisis statistik yang terdiri dari uji asumsi klasik, analisis regresi linier berganda, pengujian signifikan simultan dan pengujian signifikan parsial serta pengujian koefisien determinasi.

Pada pengujian secara serempak (uji F) diketahui bahwa pengalaman pelanggan (customer experience) yang terdiri dari variabel Sense, Feel, Think, Act dan Relate secara bersamasama berpengaruh positif dan signifikan terhadap kepuasan pelanggan. Pada pengujian secara parsial (uji t) diketahui bahwa variabel Sense, Feel, dan Think secara parsial berpengaruh positif dan signifikan terhadap kepuasan pelanggan. Sedangkan Act dan Relate berpengaruh positif dan tidak signifikan terhadap kepuasan pelanggan. Melalui pengujian koefisien determinasi diperoleh nilai Adjusted $R$ square sebesar 0,562 berarti 56,2\% kepuasan pelanggan dapat dijelaskan oleh pengalaman pelanggan (customer experience) yang terdiri dari variabel Sense, Feel, Think, Act dan Relate, sedangkan sisanya 43,8\% dapat dijelaskan oleh variabel lainn yang tidak dibahas dalam penelitian ini.
\end{abstract}

Kata kunci : Pengalaman pelanggan, Kepuasan pelanggan.

\section{Pendahuluan}

Persaingan yang ketat tersebut para pelaku usaha mencoba untuk memberikan sesuatu yang lebih kepada pelanggan. Ada pelaku usaha yang memberikan pelanggan sesuatu yang lebih dengan memperbaiki konsep dekorasi ruangan dengan menggunakan tema-tema tertentu yang dianggap sesuai dengan permintaan pasar. Selain itu ada pula pelaku usaha yang memberikan kelebihan dengan menggabungkan dekorasi yang pada dasarnya memiliki tujuan yang sama yaitu mencapai kepuasan pelanggan dan memiliki hubungan dengan pelanggan yang kemudian dapat menciptakan pelanggan yang loyal dan menjaga kesetiaan pelanggan dengan menawarkan program keanggotaan (membership), serta membuat sistem guest comment seperti kritik dan saran untuk mendapatkan feedback dari pelanggan. Seiring berjalannya waktu, para pelaku usaha dalam industri makanan mulai menyadari bahwa menciptakan pelanggan yang loyal dan menguasai pangsa pasar industri makanan tidak bisa tercapai jika hanya 
didasarkan pada konsep pemasaran, kepuasan pelanggan serta penciptaan hubungan yang baik dengan pelanggan.

Pada dasarnya tujuan dari suatu bisnis adalah untuk menciptakan para pelanggan merasa puas. Memberikan kepuasan kepada pelanggan dapat memenuhi kebutuhan, keinginan, dan harapan mereka merupakan hal yang sangat penting bagi perusahaan untuk menghadapi persaingan. Salah satu cara agar dapat merebut pangsa pasar adalah dengan memperoleh pelanggan sebanyakbanyaknya. Perusahaan akan berhasil memperoleh pelanggan dalam jumlah yang banyak apabila dinilai dapat memberikan kepuasan bagi pelanggan. Pelanggan yang puas dan setia merupakan peluang untuk mendapatkan pelanggan baru melalui rekomendasi dari mulut ke mulut. Mempertahankan semua pelanggan yang ada umumnya akan lebih menguntungkan dibandingkan dengan pergantian pelanggan karena biaya untuk menarik pelanggan baru bisa lebih besar dari biaya mempertahankan seorang pelanggan yang sudah ada. Hubungan antara fokus pada pelanggan dan tingkat kepuasan juga disadari oleh sebahagian besar perusahaan. Oleh sebab itu, banyak perusahaan saat ini sangat concern dengan pencapaian kepuasan pelanggan.

Bisnis kuliner harus dapat menciptakan sebuah strategi dengan memberikan pengalaman pada konsumen saat menikmati/mengkonsumsi produk atau jasa yang diberikan. Kepuasan konsumen dapat dicapai jika perusahaan tidak membiarkan produk atau layanan terjadi dengan sendirinya. Oleh sebab itu, perlu desain produk dan pelayanan secara terintegrasi sehingga menimbulkan pengalaman konsumen yang di sebut sebagai customer experience (pengalaman konsumen).
Berdasarkan penelitian Schmitt (Majalah Marketing 01/V/Januari, 2006) Holistic Experience (pengalaman keseluruhan) merupakan tujuan dari pemasaran yang dapat meningkatkan kepuasan pelanggan, yang artinya bahwa kepuasan akhir konsumen atau pelanggan akan diperoleh jika konsumen mampu merasakan keseluruhan pengalaman yang dibentuk. Itulah sebabnya, Schmitt menggagas experiental marketing sebagai pendekatan baru yang lebih tepat untuk memberikan kepuasan maksimal pada konsumen. Dalam menciptakan kepuasan konsumen tersebut, perusahaan perlu mengembangkan terus rancangan produk dan pelayanan, yang terintegrasi untuk dapat memenuhi kebutuhan dan keinginan konsumen.

Pengalaman konsumen (customer experience) adalah sebuah strategi yang hadir pada zaman revolusi industri, di mana sektor agrikultur tergeser oleh sektor manufaktur, seiring dengan meningkatnya keadaan ekonomi masyarakat dan proses otomatisasi, sehingga penghasilan masyarakat bertambah dan memiliki lebih banyak waktu luang sehingga masyarakat lebih memilih untuk membeli pelayanan (services) di banding hanya memperoleh kebutuhan yang di harapkan baik barang maupun jasa. Dalam hal ini pengukuran kepuasan pada customer experience dengan menggunakan 5 (lima) dimensi yaitu sense, feel, think, act dan relate. Pengalaman ini dapat dilihat dari sisi bagaimana konsumen mengkonsumsi atau menggunakan produk itu, dalam situasi apa konsumen mengkonsumsinya, bagaimana keterlibatan konsumen dalam proses konsumsi atau penggunaan produk.

Salah satu usaha yang menerapkan strategi tersebut adalah Rumah Makan 
Kuliner Jawa. Rumah Makan Kuliner Jawa merupakan salah jenis usaha kecil yang bergerak dalam bisnis makanan (kuliner). Konsumen sejak pertama kali berkunjung ke Rumah Makan Kuliner Jawa sudah dihadapkan dengan keadaan yang ramai dan tempat yang cukup luas dan nyaman. Penulis memilih Rumah Makan Kuliner Jawa sebagai tempat penelitian, karena Rumah Makan ini menyediakan beberapa jenis menu makanan khas jawa, seperti ayam penyet, pecel lele, ikan bakar, dan lain-lain. Selain itu, tentu saja kualitas dan harga produk yang ditawarkan mampu bersaing dengan rumah makan lain sehingga dapat terus mengembangkan usahanya dalam kondisi ekonomi yang krisis seperti sekarang ini.

\section{Tinjauan Pustaka}

Model customer experience adalah suatu model dalam pemasaran yang mengikuti customer equity. Model ini dikembangkan oleh Bern Schmitt dalam bukunya Customer Experience Management, yang merupakan kelanjutan dari buku sebelumnya, yaitu Experiential Marketing.

Menurut Schmitt (dalam

Fauziyah, 2011:11), experience adalah peristiwa pribadi yang terjadi sebagai jawaban atas beberapa rangsangan. Pengalaman atau experience melibatkan seluruh dalam setiap peristiwa kehidupan. Dengan kata lain, sebagai pemasar harus menata lingkungan yang benar untuk pelanggan dan apa sebenarnya yang diinginkan pelanggan. Pengalaman atau experience pada umumnya bukan dihasilkan atas diri sendiri tapi bersifat membujuk pada atau secara psikologi pengalaman adalah sesuatu hal yang terjadi tanpa kesengajaan.
Experiential

Marketing merupakan sebuah pendekatan baru untuk memberikan informasi mengenai merek dan produk. Hal ini terkait erat dengan pengalaman pelanggan dan sangat berbeda dengan pemasaran tradisional yang berfokus pada fungsi dan keuntungan sebuah produk (Andreani, 2007:2). Menurut Schmitt (dalam Andreani, 2007:3), "Customer Experience Management (CEM) is the process of strategically managing a customer's entire experience with a product or a company". Customer experience management adalah proses secara strategis dalam mengatur atau implementasi pengalaman atas diri pelanggan dengan suatu produk atau perusahaan. Sedangkan menurut Jacques (dalam Sulistiyarini, 2009:3) "Customer Experience is the quality of the experience as apprehended by a customer resulting from direct or indirect contact with any touch point of a company".

Dari pengertian di atas maka customer experience merujuk pada pengalaman nyata pelanggan terhadap merek, produk atau pelayanan untuk meningktkan penjualan dan kesadaran merek. Dalam hal ini lebih dari sekedar memberikan informasi dan peluang pada pelanggan untuk memperoleh pengalaman atas keuntungan yang di dapat dari produk atau jasa itu sendiri tapi juga membangkitkan emosi dan perasaan yang berdampak terhadap pemasaran, khususnya penjualan produk dan jasa.

$$
\text { Menurut Schmitt (dalam }
$$

Andreani, 2007:3), ada 5 dimensi customer experience antara lain :

1) Sense, berkaitan dengan gaya (styles), verbal dan visual yang mampu menciptakan keutuhan sebuah kesan. Pendekatan pemasaran dengan tujuan untuk merasakan dengan menciptakan 
pengalaman yang berhubungan dengan perasaan melalui tinjauan dengan menyentuh, merasakan, dan mencium dengan kata lain yang berhubungan dengan panca indera, yang meliputi tentang gaya, tema dan warna.

2) Feel perasaan di sini sangatlah berbeda dengan kesan sensorik karena hal ini berkaitan dengan suasana hati dan emosi jiwa seseorang. Ini bukan sekedar menyangkut keindahan, tetapi suasana hati dan emosi jiwa yang mampu membangkitkan kebahagiaan atau bahkan kesedihan. Merupakan perasaan emosi yang muncul dari dalam hati secara positif dan perasaan gembira yang terjadi pada saat mengkonsumsi. Unsur sense meliputi tentang suasana hati dan perasaan atau emosi positif.

3) Think merupakan pemikiran kreatif yang muncul di benak konsumen akan suatu merek/perusahaan atau pelanggan diajak untuk terlibat dalam pemikiran kreatif. Prinsip think terdiri atas 3 yaitu surprise, intrigue, dan provocation.

4) Act berkaitan dengan perilaku yang nyata dan gaya hidup seseorang. Hal ini berhubungan dengan bagaimana membuat orang berbuat sesuatu dan mengekspresikan gaya hidupnya. Strategi marketing Act dirancang untuk menciptakan pengalaman pelanggan yang berhubugan dengan gerakan badan atau dengan kata lain gerakan dan interaksi yang muncul. Act Experience meliputi flesh yang berhubungan dengan tubuh, tidak hanya mendatangkan sensasi dan perspesi mengenai dunia luar, motor action (aksi mesin) juga ikut bekerja dengan penuh yang dapat menimbulkan interaksi (interact), karena berhubungan erat dengan perilaku fisik atas gaya hidup dan dari pihak-pihak yang berinteraksi.

5) Relate merupakan upaya untuk menghubungkan dirinya dengan orang lain, dirinya dengan merek atau perusahaan, dan budaya. Hal ini berkaitan dengan budaya seseorang dan kelompok referensinya yang dapat menciptakan identitas. Seorang pemasar harus mampu menciptakan identitas (generasi, kebangsaan, etnis) bagi pelanggannya dengan produk atau jasa yang ditawarkan. Pemasar dapat menggunakan budaya dalam kampanye iklan dan desain Web yang mampu mengidentifikasikan kelompok pelanggan tertentu.

Kepuasan (satisfaction) berasal dari bahasa Latin "satis" (artinya cukup baik, memadai) dan "factio" (artinya melakukan atau membuat). Secara sederhana, kepuasan dapat diartikan sebagai upaya pemenuhan sesuatu atau membuat sesuatu memadai (Tjiptono, 2011:349).

Menurut Simamora (2008: 18), kepuasan pelanggan adalah hasil pengalaman terhadap produk. Ini adalah sebuah perasaan konsumen setelah membandingkan antar harapan dengan kinerja aktual produk. Sedangkan menurut Kotler (2006: 13), kepuasan pelanggan adalah suatu tingkatan dimana perkiraan kinerja produk sesuai dengan harapan pembeli.

Berdasarkan defenisi-defenisi diatas, dapat disimpulkan bahwa kepuasan merupakan fungsi dari kesan terhadap kinerja dengan harapan. Jika kinerja berada dibawah harapan, maka pelanggan tidak puas, tetapi jika kinerja melebihi harapan, maka pelanggan merasa puas.

Kerangka konseptual dalam penelitian ini adalah variabel-variabel 
pengalaman pelanggan (customer experience) seperti pada gambar berikut :

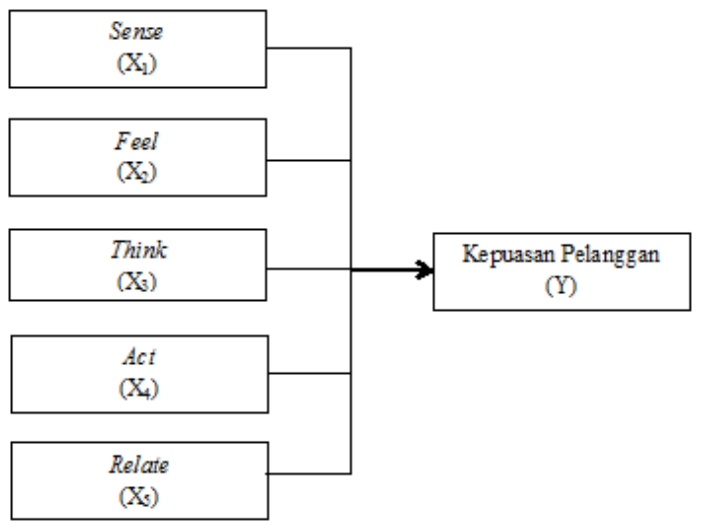

Sumber : Andreani (2007, Fauziyah (2011), dan Kotler (2006) (diolah)

\section{Gambar 1. Kerangka Konseptual}

Hipotesis merupakan jawaban sementara terhadap rumusan masalah penelitian, oleh karena itu rumusan masalah penelitian biasanya disusun dalam bentuk kalimat pertanyaan (Sugiyono, 2010:93). Berdasarkan perumusan masalah dan kerangka konseptual yang diberikan maka peneliti merumuskan hipotesis sebagai berikut :

1. Sense berpengaruh positif dan signifikan terhadap kepuasan pelanggan pada Rumah Makan Kuliner Jawa Rantauprapat.

2. Feel berpengaruh positif dan signifikan terhadap kepuasan pelanggan pada Rumah Makan Kuliner Jawa Rantauprapat.

3. Think berpengaruh positif dan signifikan terhadap kepuasan pelanggan pada Rumah Makan Kuliner Jawa Rantauprapat.

4. Act berpengaruh positif dan signifikan terhadap kepuasan pelanggan pada Rumah Makan Kuliner Jawa Rantauprapat.

5. Relate berpengaruh positif dan signifikan terhadap kepuasan pelanggan pada Rumah Makan Kuliner Jawa Rantauprapat.

6. Sense, Feel, Think, Act, dan Relate berpengaruh positif dan signifikan kepuasan pelanggan pada Rumah Makan Kuliner Jawa Rantauprapat.

\section{Metode Penelitian \\ Populasi dan Sampel}

Populasi adalah sekelompok elemen yang lengkap, yang biasanya berupa orang, objek atau kejadian dimana kita tertarik untuk mempelajari suatu objek penelitian (Kuncoro, 2009:115). Yang menjadi populasi dalam penelitian ini adalah pelanggan Rumah Makan Kuliner Jawa yang jumlahnya tidak dapat ditentukan secara pasti.

Karena populasi dalam penelitian ini tidak diketahui jumlahnya, menurut Wibisono (dalam Riduwan dan Akdon, 2013 : 255) jumlah sampel yang digunakan adalah 96 orang.

\section{Defenisi Operasional Variabel Tabel 1 Defenisi Operasional Variabel}

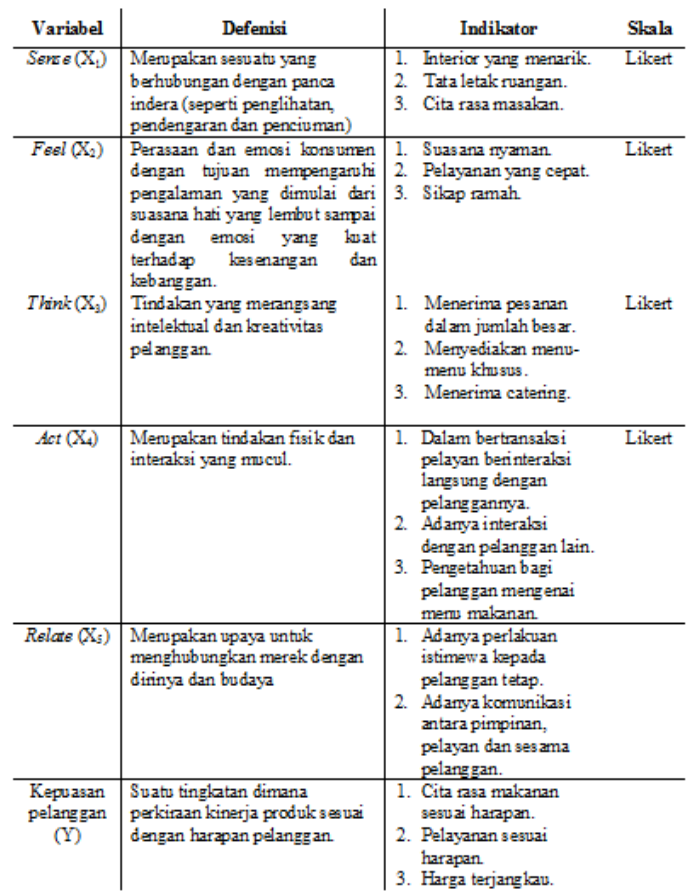




\section{Teknik Pengumpulan Data}

Teknik yang digunakan dalam pengumpulan data pada penelitian ini ialah :

\section{Kuesioner}

Menyebarkan daftar pertanyaan yang telah diberikan alternatif jawaban untuk menjawabnya kepada responden terpilih.

2. Wawancara

Wawancara secara langsung dengan responden dan pihak-pihak terkait.

3. Studi Pustaka

Yaitu dengan mengumpulkan dan mempelajari informasi dan data-data yang diperoleh jurnal, buku-buku literatur, majalah dan internet yang terkait dengan penelitian ini.

\section{Hasil Dan Pembahasan}

\section{Analisis Regresi Linear Berganda}

Analisis regresi linear berganda digunakan untuk mengetahui berapa besar pengaruh variabel bebas (Sense, Feel, Think, Act, dan Relate) terhadap variabel terikat (kepuasan pelanggan). Maka untuk memperoleh hasil yang lebih akurat digunakan program software SPSS 20.0 for windows, maka dari Tabel coefficient dihasilkan output sebagai berikut :

Tabel 2 Analisis Regresi Linear Berganda

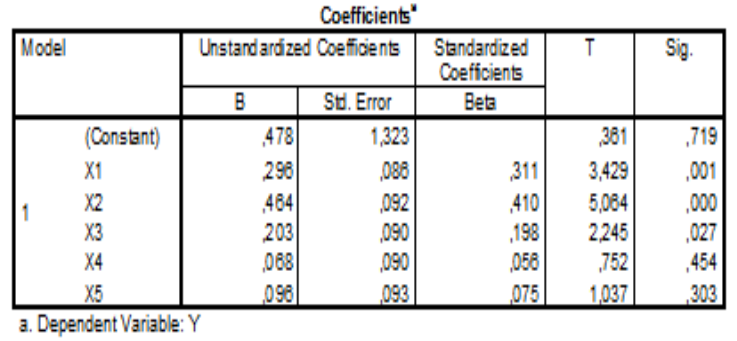

Sumber : Hasil Pengolahan Data SPSS (2016)

Berdasarkan hasil pengolahan data seperti terlihat pada Tabel diatas, Kolom Unstandardized Coefficients bagian B diperoleh persamaan regresi linier berganda

$$
Y=0,478+0,296 X_{1}+0,464 X_{2}+
$$

$0,203 X_{3}+0,068 X_{4}+0,096 X_{5}+e$

Berdasarkan persamaan tersebut dapat dijelaskan sebagai berikut :

1) Konstanta (a) $=0,478$. Ini mempunyai arti bahwa apabila variabel Sense, Feel, Think, Act dan Relate dianggap tidak ada (bernilai nol), maka kepuasan pelanggan sebesar 0,478 .

2) Koefisien $X_{1} \quad\left(b_{1}\right)=0,296$. Ini mempunyai arti bahwa jika variabel Sense naik 1 satuan dan variabel lainnya konstan, maka kepuasan pelanggan naik sebesar 0,296.

3) Koefisien $X_{2} \quad\left(b_{2}\right)=0,464$. Ini mempunyai arti bahwa jika variabel Feel naik 1 satuan dan variabel lainnya konstan, maka kepuasan pelanggan naik sebesar 0,464.

4) Koefisien $X_{3} \quad\left(b_{3}\right)=0,203$. Ini mempunyai arti bahwa jika variabel Think naik 1 satuan dan variabel lainnya konstan, maka kepuasan pelanggan naik sebesar 0,203.

5) Koefisien $X_{4} \quad\left(b_{4}\right)=0,068$. Ini mempunyai arti bahwa jika variabel Act naik 1 satuan dan variabel lainnya konstan, maka kepuasan pelanggan naik sebesar 0,068 .

6) Koefisien $X_{5} \quad\left(b_{5}\right)=0,096$. Ini mempunyai arti bahwa jika variabel Relate naik 1 satuan dan variabel lainnya konstan, maka kepuasan pelanggan naik sebesar 0,096.

\section{Pengujian Hipotesis Uji Signifikansi Parsial (Uji t)}

Uji t ini menunjukkan seberapa besar pengaruh variabel bebas $(\mathrm{X})$ secara parsial/individu terhadap variabel terikat (Y). Uji $t$ dilakukan dengan cara membandingkan nilai $t_{\text {hitung }}$ dengan $t_{\text {tabel }}$ 
dengan kriteria pengambilan keputusan adalah :

- $\mathrm{H}_{0}$ diterima jika $\mathrm{t}_{\text {hitung }}<\mathrm{t}_{\text {tabel }}$ pada $\alpha=5 \%$.

- Ha diterima jika $t_{\text {hitung }}>\mathrm{t}_{\text {tabel }}$ pada $\alpha=5 \%$.

Nilai $t_{\text {hitung diperoleh dengan }}$ menggunakan software SPSS 20.0 for Windows, kemudian akan dibandingkan dengan nilai $t_{\text {tabel }}$ pada tingkat $\alpha=5 \%$ yakni yang diperoleh dengan derajat bebas $=\mathrm{df}-\mathrm{k}(\mathrm{df}=$ jumlah sampel dan $\mathrm{k}$ $=$ jumlah variabel keseluruhan) yaitu df1 $=6-1=5$, dan df $2=96-6=90$. Uji thitung yang dilakukan adalah uji dua arah maka $\mathrm{t}_{\text {tabel }}$ yang digunakan adalah $\mathrm{t} 5 \%$ atau $\mathrm{t}_{0,05}$ $(90)=1,66196=1,662$.

\section{Tabel 3 Hasil Uji Parsial (Uji t)}

Coefficients"

\begin{tabular}{|c|c|c|c|c|c|c|}
\hline \multirow[t]{2}{*}{ Mod } & & \multicolumn{2}{|c|}{ Unstandarózed Coeficients } & \multirow{2}{*}{$\begin{array}{l}\text { Sandardized } \\
\text { Coeficients } \\
\text { Beta }\end{array}$} & \multirow[t]{2}{*}{$t$} & \multirow[t]{2}{*}{ Sig. } \\
\hline & & $B$ & St, Error & & & \\
\hline \multirow{6}{*}{1} & (Constant) & .478 & 1,323 & & 381 &, 719 \\
\hline & $X_{1}$ & 298 & 088 & 311 & 3,429 &, 001 \\
\hline & $\times 2$ &, 464 &, 092 & .410 & 5,084 &, 000 \\
\hline & $x_{3}$ & 203 &, 090 & 198 & 2245 &, 027 \\
\hline & $x_{4}$ &, 088 &, 090 &, 058 &, 752 & .454 \\
\hline & $\times 5$ & $, 0,080$ &, 093 &, 075 & 1,037 &, 303 \\
\hline
\end{tabular}

Berdasarkan Tabel di atas, maka dapat dijelaskan sebagai berikut :

a) Sense $\left(\mathrm{X}_{1}\right)$ berpengaruh positif dan signifikan terhadap kepuasan pelanggan $(\mathrm{Y})$, hal ini dilihat dari nilai $t_{\text {hitung }}(3,429)>t_{\text {tabel }}(1,662)$ dengan taraf signifikan 0,001 $<0,05$. Dengan demikian hipotesis dapat diterima.

b) Feel $\left(\mathrm{X}_{2}\right)$ berpengaruh positif dan signifikan terhadap kepuasan pelanggan $(\mathrm{Y})$, hal ini dilihat dari nilai $t_{\text {hitung }}(5,064)>t_{\text {tabel }}(1,662)$ dengan taraf signifikan $0,000<0,05$. Dengan demikian hipotesis dapat diterima.

c) Think $\left(\mathrm{X}_{3}\right)$ berpengaruh positif dan signifikan terhadap kepuasan pelanggan $(\mathrm{Y})$, hal ini dilihat dari nilai $t_{\text {hitung }}(2,245)>t_{\text {tabel }}(1,662)$ dengan taraf signifikan $0,028<0,05$. Dengan demikian hipotesis dapat diterima.

d) Act $\left(\mathrm{X}_{4}\right)$ berpengaruh positif dan tidak signifikan terhadap kepuasan pelanggan (Y), hal ini dilihat dari nilai $t_{\text {hitung }}(0,752)<t_{\text {tabel }}(1,662)$ dengan taraf signifikan 0,454 >0,05. Dengan demikian hipotesis ditolak.

e) Relate $\left(\mathrm{X}_{5}\right)$ berpengaruh positif dan tidak signifikan terhadap kepuasan pelanggan (Y), hal ini dilihat dari nilai $t_{\text {hitung }}(1,037)<t_{\text {tabel }}(1,662)$ dengan taraf signifikan $0,303>0,05$. Dengan demikian hipotesis ditolak.

\section{Uji Signifikansi Simultan (Uji F)}

Uji F (uji serentak) dilakukan untuk melihat secara bersama-sama pengaruh atau hubungan positif dan signifikan variabel bebas $\left(\mathrm{X}_{1}, \mathrm{X}_{2}\right.$, dan $\left.\mathrm{X}_{3}\right)$ berupa variabel Sense, Feel, Think, Act, dan Relate dan variabel terikat (Y) berupa kepuasan pelanggan.

Nilai $F_{\text {hitung }}$ diperoleh dengan menggunakan software SPSS 20.0 for Windows, kemudian akan dibandingkan dengan nilai $F_{\text {tabel }}$ pada tingkat $\alpha=5 \%$ dengan derajat bebas yaitu df1 $=6-1=5$, dan df $2=96-6=90$. Maka $F_{\text {tabel }}$ yang digunakan adalah nilai $\mathrm{F}_{0,05}(5: 90)=2,32$.

Tabel 4 Hasil Uji Simultan (Uji F)

\begin{tabular}{|c|c|c|c|c|c|c|}
\hline \multicolumn{7}{|c|}{ ANOVA" } \\
\hline Mode & & Sum of Souares & $\overline{D f}$ & Mean Souare & $\bar{F}$ & $\operatorname{Sig}$. \\
\hline \multirow{3}{*}{1} & Regression & 83,787 & 5 & 12,753 & 25,398 &, $000^{2}$ \\
\hline & Residual & 45,192 & 90 & 502 & & \\
\hline & Total & 108,958 & 95 & & & \\
\hline
\end{tabular}

Sumber : Hasil Pengolahan Data SPSS, 2016

Berdasarkan Tabel diatas bahwa nilai $F_{\text {hitung }}>F_{\text {tabel }}(25,398>2,32)$ dengan taraf signifikansi $0,000<0,05$ menunjukkan bahwa Sense, Feel, Think, Act, dan Relate secara serempak atau 
bersama-sama berpengaruh positif dan signifikan terhadap kepuasan pelanggan. Dengan demikian hipotesis dapat diterima.

\section{Koefisien Determinasi $\left(\boldsymbol{R}^{2}\right)$}

Pengujian koefisien determinasi $\left(R_{2}\right)$ bertujuan untuk mengetahui seberapa besar kemampuan variabel bebas menjelaskan variabel terikat. Dalam output SPSS, koefisien determinasi terletak pada tabel Model Summary dan tertulis $R$ Square. Namun untuk regresi linear berganda sebaiknya menggunakan nilai $R$ Square yang sudah disesuaikan atau tertulis Adjusted $R$ Square, karena disesuaikan dengan jumlah variabel bebas dalam penelitian. Nilai $R$ Square dikatakan baik jika di atas 0,5 karena nilai $R$ Square berkisar antara 0 sampai 1 .

Tabel 5 Koefisien Determinasi

\begin{tabular}{|c|c|c|c|c|}
\hline \multicolumn{5}{|c|}{ Model Summary } \\
\hline Model & $R$ & R Square & $\begin{array}{c}\text { Adjusted R } \\
\text { Square }\end{array}$ & $\begin{array}{l}\text { St. Error of the } \\
\text { Estimate }\end{array}$ \\
\hline 1 & $785^{\circ}$ & 585 & ,562 & ,70881 \\
\hline
\end{tabular}

Sumber : Hasil Pengolahan Data SPSS, 2016

Berdasarkan Tabel diatas dapat dijelaskan sebagai berikut :

a) Nilai $R=0,765$ berarti hubungan antara Sense $\left(\mathrm{X}_{1}\right)$, Feel $\left(\mathrm{X}_{2}\right)$, Think $\left(\mathrm{X}_{3}\right)$, Act $\left(\mathrm{X}_{4}\right)$ dan Relate $\left(\mathrm{X}_{5}\right)$ terhadap kepuasan pelanggan (Y) sebesar $76,5 \%$. Artinya hubungan antar variabel erat atau kuat.

b) Nilai Adjusted $R$ square sebesar 0,562 berarti $56,2 \%$ kepuasan pelanggan dapat dijelaskan oleh variabel Sense $\left(\mathrm{X}_{1}\right)$, Feel $\left(\mathrm{X}_{2}\right)$, Think $\left(\mathrm{X}_{3}\right)$, Act $\left(\mathrm{X}_{4}\right)$ dan Relate $\left(\mathrm{X}_{5}\right)$. Sedangkan sisanya 43,8\% dapat dijelaskan oleh faktor lain yang tidak diteliti oleh penelitian ini. c) Standard Error of Estimated (standar deviasi) bernilai 0,70861 yang berarti model regresi dinilai baik, karena semakin kecil standar deviasi berarti model akan semakin baik.

\section{Pembahasan}

Berdasarkan hasil uji hipotesis secara parsial (uji t) diperoleh nilai $t_{\text {hitung }}$ $(3,429)>t_{\text {tabel }}(1,662)$ dengan taraf signifikan $0,001<0,05$. Hasil ini menunjukkan bahwa variabel Sense berpengaruh positif dan signifikan terhadap kepuasan pelanggan pada Rumah Makan Kuliner Jawa. Dalam hal ini, Sense experience yang diberikan Rumah Makan Kuliner Jawa melalui desain interior ruangan yang menarik, tata letak ruangan yang rapi, dan cita rasa amsakan yang enak dapat menimbulkan persepsi yang baik dimata pelanggan serta telah memenuhi kepuasan pelanggan Rumah Makan Kuliner Jawa.

Berdasarkan hasil uji hipotesis secara parsial (uji t) diperoleh nilai $t_{\text {hitung }}$ $(5,064)>t_{\text {tabel }}(1,662)$ dengan taraf signifikan $0,00<0,05$. Hasil ini menunjukkan bahwa variabel Feel berpengaruh positif dan signifikan terhadap kepuasan pelanggan pada Rumah Makan Kuliner Jawa. Artinya bahwa Feel experience yang ditawarkan oleh Rumah Makan Kuliner Jawa menimbulkan emosi positif dalam servis pelayan yang bagus, pelayan yang ramah dan suasana yang nyaman. Jika Feel experience ini ditingkatkan maka cenderung juga pada akhirnya meningkatkan kepuasan konsumen.

Berdasarkan hasil uji hipotesis secara parsial (uji t) diperoleh nilai $t_{\text {hitung }}$ $(2,245)>t_{\text {tabel }}(1,662)$ dengan taraf signifikan $0,028<0,05$. Hasil ini menunjukkan bahwa variabel Think berpengaruh positif dan signifikan terhadap kepuasan pelanggan pada 
Rumah Makan Kuliner Jawa. Variabel Think experience berhubungan erat dengan pikiran kreatif pelanggan. Artinya jika Rumah Makan Kuliner Jawa dapat menghadirkan Think experience dalam bentuk menerima pesanan dalam partai besar, menyediakan menu-menu merangsang atau memicu Think experience pelanggan yang pada akhirnya dapat memenuhi kepuasan pelanggan.

Berdasarkan hasil uji hipotesis secara parsial (uji t) diperoleh nilai $t_{\text {hitung }}$ $(0,752)<t_{\text {tabel }}(1,662)$ dengan taraf signifikan $0,454>0,05$. Hasil ini menunjukkan bahwa variabel Act berpengaruh positif dan tidak signifikan terhadap kepuasan pelanggan pada Rumah Makan Kuliner Jawa. Variabel Act Experience yang berhubungan dengan interaksi pelayan dengan pelanggan mampu memberikan kepuasan pelanggan tetapi pengaruhnya tidak besar (signifikan). Atau dengan kata lain, meskipun interaksi dengan pelanggan baik tetapi tidak terlalu mempengaruhi kepuasan pelanggan.

Berdasarkan hasil uji hipotesis secara parsial (uji t) diperoleh nilai $t_{\text {hitung }}$ $(1,037)<t_{\text {tabel }}(1,662)$ dengan taraf signifikan $0,303>0,05$. Hasil ini menunjukkan bahwa variabel Relate berpengaruh positif dan tidak signifikan terhadap kepuasan pelanggan pada Rumah Makan Kuliner Jawa. Relate dalam hal ini sebagai tipe experience yang digunakan untuk mempengaruhi pelanggan dan menggabungkan seluruh aspek Sense, Feel, Think, dan Act serta menitikberatkan pada penciptaan persepsi positif di mata pelanggan. Dalam arti pelanggan datang ke Rumah Makan Kuliner Jawa bukan dengan sendirinya tetapi ikut mengkonsumsi bersama suatu kelompok atau kolega. Oleh karena itu, pelayanan Rumah Makan Kuliner Jawa tidak boleh mengutamakan atau mengistimewakan pelanggan tertentu saja, melainkan harus bersikap adil terhadap semua pelanggan. Apabila hanya mengutamakan atau mengistimewakan pelanggan tertentu saja maka akan menimbulkan ketidakpuasan bagi pelanggan yang lain. Pihak Rumah Makan Kuliner Jawa lebih menekankan hal hubungan dan komunikasi yang baik dengan semua pelanggan atau kelompok pelanggan supaya Relate experience terpenuhi dalam Rumah Makan Kuliner Jawa yang pada akhirnya timbul kesan positif di benak pelanggan.

\section{Kesimpulan}

Berdasarkan hasil penelitian dan pembahansan, maka dapat diambil kesimpulan sebagai berikut :

1. Secara simultan (bersama-sama), pengalaman pelanggan (customer experience) yang terdiri dari Sense $\left(\mathrm{X}_{1}\right)$, Feel $\left(\mathrm{X}_{2}\right)$, Think $\left(\mathrm{X}_{3}\right)$, Act $\left(\mathrm{X}_{4}\right)$ dan Relate $\left(\mathrm{X}_{5}\right)$ berpengaruh secara positif dan signifikan terhadap kepuasan pelanggan (Y) pada Rumah Makan Kuliner Jawa. Hal ini dapat diketahui dari nilai $\mathrm{F}_{\text {hitung }}>\mathrm{F}_{\text {tabel }}$ $(25,398>2,32)$ dengan taraf signifikansi $0,000<0,05$.

2. Secara parsial, pengalaman pelanggan (customer experience) yang berpengaruh secara positif dan signifikan terhadap kepuasan pelanggan terdiri dari tiga variabel, yaitu variabel Sense $\left(\mathrm{X}_{1}\right)$, Feel $\left(\mathrm{X}_{2}\right)$, dan Think $\left(\mathrm{X}_{3}\right)$. Hal ini dapat diketahui dari nilai $t_{\text {hitung variabel Sense }}(3,429)$ $>t_{\text {tabel }}(1,662)$ dengan taraf signifikan $0,001<0,05$. Nilai $t_{\text {hitung variabel Feel }}$ $(5,064)>t_{\text {tabel }}(1,662)$ dengan taraf signifikan $0,000<0,05$. Nilai $t_{\text {hitung }}$ variabel Think $(2,245)>\mathrm{t}_{\text {tabel }}(1,662)$ dengan taraf signifikan $0,028<0,05$. 
Sementara variabel Act $\left(\mathrm{X}_{4}\right)$ dan Relate $\left(\mathrm{X}_{5}\right)$ berpengaruh positif dan tidak signifikan terhadap kepuasan pelanggan, dimana nilai $t_{\text {hitung }}$ variabel Act $(0,752)<\mathrm{t}_{\text {tabel }}(1,662)$ dengan taraf signifikan $0,454>0,05$, dan nilai $t_{\text {hitung }}$ variabel Relate $(1,037)<\mathrm{t}_{\text {tabel }}(1,662)$ dengan taraf signifikan 0,303>0,05.

3. Hasil Uji Determinasi diperoleh angka Adjusted $R$ Square sebesar 0,562. Nilai tersebut berarti bahwa pengaruh Sense, Feel, Think, Act dan Relate terhadap kepuasan pelanggan adalah 56,2\%. Adapun sisanya sebesar 43,8\% (100\% - 56,2\%) dipengaruhi oleh faktor lain yang tidak termasuk dalam variabel pengalaman pelanggan (customer experience) yang tidak diikutsertakan dalam penelitian ini.

\section{Saran}

Berdasarkan kesimpulan diatas, maka peneliti memberikan saran sebagai berikut :

1. Hasil penelitian menunjukkan pengalaman pelanggan (customer experience) bahwa variabel Feel mempunyai pengaruh yang positif dan signifikan dan paling dominan terhadap kepuasan pelanggan. Konsumen menganggap bahwa Feel yang diberikan oleh Rumah Makan Kuliner Jawa memenuhi harapan mereka. Untuk itu, faktor tersebut perlu dipertahankan dan juga ditingkatkan oleh Rumah Makan Kuliner Jawa. Dimensi Feel, memberikan servis yang bagus kepada pelanggan, pelayan yang ramah yang dapat menimbulkan emosi positif pelanggan dan melakukan differensiasi jasa ditengah persaingan yang ada sekarang ini demi memenuhi kepuasan pelanggan.
2. Peneliti lain yang akan meneliti tentang pengalaman pelanggan (customer experience) untuk waktu ke depannya, disarankan untuk dapat memfokuskan pada beberapa variabelvariabel dari pengalaman pelanggan (customer experience) agar sasaran dan tujuan penelitian dapat tercapai secara maksimal. Sesuai dengan teori Schmitt. Oleh karena itu, penelitian selanjutnya agar dapat menyesuaikan variabel penelitian yang disesuaikan dengan penelitian.

\section{Daftar Pustaka}

Andreani, Fransisca. "Experiental Marketing", Jurnal Manajemen Pemasaran. Vol 2. No.1, April, 2007 : $1-8$, http/puslit petra.ac.id/journals marketing.

Fauziyah, Resty. 2011. "Pengaruh Customer Experience Terhadap Kepuasan Konsumen pada Supermarket Madinah Syariah Medan". Jurnal Ekonomi dan Bisnis. Medan : USU.

Gea, Jonathan. 2007. "Analisis Customer Experience Timezone Thamrin plaza Medan”. Jurnal. Medan : FE - USU.

Ghozali, Imam. 2007. Aplikasi Analisis Multivariate dengan Program SPSS. Semarang : Badan Penerbit Universitas Diponegoro.

Kotler, Philip. 2006. Manajemen Pemasaran : Analisis, Perencanaan, Implementasi dan Kontrol. Jakarta : PT. Prehallindo.

2008. Manajemen Pemasaran. Jilid 1 dan 2. Jakarta : PT. Indeks. 
Kuncoro, Mudrajad. 2009. Metode Riset untuk Bisnis \& Ekonomi (Edisi 3). Jakarta : Erlangga.

Lupiyoadi, Rambat. 2006. Manajemen Pemasaran Jasa, Teori dan Praktek. Edisi Pertama. Jakarta : Salemba Empat.

Mowen, Jhon $\mathrm{C}$ dan Michael Minor. 2008. Perilaku Konsumen. Alih Bahasa : Dwi Kartini. Edisi Kelima. Jakarta : Erlangga.

Riduwan dan Akdon. 2013. Rumus dan Data dalam Analisis Statistika. Bandung : Alfabeta.

Sianipar, Selamat O. 2008. "Analisis Pengaruh Customer Experience Terhadap Kepuasan Konsumen Pada Amazone Sun Plaza Medan". Jurnal. Medan : FEUSU.

Simamora, Bilson. 2008. Membongkar Kotak Hitam Konsumen. Jakarta: PT. Gramedia Pustaka.

Situmorang, Syafrizal Helmi, dkk. 2008. Analisis Data Penelitian (Menggunakan Program SPSS). Medan : USU Press.

Sugiyono. 2010. Metode Penelitian Kuantitatif, Kualitatif dan $R \&$ $D$. Bandung : Alfabeta.

Sulistyarini, Endang. 2009. "Menciptakan Pengalaman Konsumen dengan Experiental Marketing". Jurnal Manajemen Bisnis. Medan : USU Press.

Sunarto. 2006. Prinsip-Prinsip Pemasaran. Yogyakarta : Amus.

Tjiptono, Fandy. 2011. Pemasaran Jasa. Edisi Pertama. Jawa Timur : Bayumedia Publishing.

Usman, Hardius dan Nurdin Sobari. 2013. Aplikasi Teknik Multivariate untuk Riset Pemasaran. Jakarta : PT. Raja Grafindo Persada. 